\title{
Margaret McCartney: The social care system has become inherently unsafe
}

\author{
Margaret McCartney general practitioner
}

Glasgow

Ellen Ash was an elderly woman with severe dementia, who lived in Glasgow. She died in 2013 after she was smothered and her house was set on fire. Her son, Jeffrey, went to the police the next day to confess to both. ${ }^{1} \mathrm{He}$ was her carer and seems to have been under immense stress.

Social care is under intense pressure but also scrutiny. Over the past few months this complex case has been discussed at wide ranging, interdisciplinary meetings involving health and social care staff. In Scotland, social and health care are integrated in law. But in practice?

In the months before her death Ash was admitted to hospital for various reasons, including hypothermia, and with an area of necrotic tissue. "Neglect" and "vulnerability" were mentioned in her case notes. After her death a public significant case review found multiple failings and errors. Communication between social work and health teams was found serially wanting, and services such as day care were offered but never materialised. ${ }^{2}$

Nothing about the current health and social care system suggests that something similar couldn't happen again. It seems as though health and social care professionals hardly know each other.

How many of us haven't faced a patient who's judged to need residential care but declines it? How many families do we know with a precarious home situation involving some-but probably not enough-care input? How many people are lost to follow-up? How many referrals to an agency are rejected? We may not know which agencies are even involved. How often are we unsure whether an appropriate review has been completed?

Social care has become fragmented by design. In Glasgow, Cordia was set up as an arm's length company to provide home caring services rather than staff being directly employed by the council (some suggest that this was done for the council to avoid equal pay claims ${ }^{3}$ ). This has meant that home carers, who used to be directly employed by the council and worked from inside the social work department, are now outside it.

To me, social care seems to be filled with committed and overworked people in an immensely hierarchical, rule bound system. Referrals into and out of care agencies are regulated, with many time consuming assessments. The community team is dissolving, and our district nurses no longer work, long term, from the practice as part of our team but "horizontally," across many.

This may be "agile," but it loses the longer term, soft knowledge on which harder decisions are based. No basic record exists between district nurses and GPs, social work, and care agencies to say who's involved. I can alert social workers to concerns, but what then? Everyone is working over capacity, in workplaces not designed to ensure that professionals have the minimum information to do the job safely.

Home carers, who used to be directly employed by the council and worked from inside the social work department, are now outside it

Forget high tech, big data innovation: we first need to sort out the basics of how the NHS, social workers, and care agencies work together. It is inherently, fundamentally, an unsafe system. And this is tragic, because the home carers and social workers I meet are entirely devoted to their jobs and work way beyond their hours and job specifications to do their work well. I've spent the past couple of weeks reading manifesto commitments, but nothing's as dull as sorting this.

Teams are important in healthcare, to bring skills together and ensure that a plan is shared, organised, and implemented. The skills are willing; the organisational ability is not. Having time to discuss difficult issues with a fellow professional offers the kind of support that we know makes care better and the job easier, but it keeps getting squeezed out.

Time to think, consider, and reflect with our social work and carer colleagues: when did we last have that? And isn't everyone the worse for it?

Competing interests: See www.bmj.com/about-bmj/freelancecontributors/margaret-mccartney.

Provenance and peer review: Commissioned; not externally peer reviewed.

Follow Margaret on Twitter, @mgtmccartney 
1 Judiciary of Scotland. HMA $v$ Jeffrey Ash. www.scotland-judiciary.org.uk/8/1130/HMA-vJEFFREY-ASH.

2 Adult Protection Committee. Glasgow City Council. Significant case review undertaken on behalf of Glasgow APC on Mrs Ellen Ash. https://www.glasgowadultprotection.org.uk CHttpHandler.ash $x$ ?id $=30627 \& p=0$.
3 Braiden G. Ruling threatens 4000 equal pay claims. Glasgow Herald 7 Jan 2012. www. heraldscotland.com/news/13044157.Ruling_threatens_4000_equal_pay_claims/.

Published by the BMJ Publishing Group Limited. For permission to use (where not already granted under a licence) please go to http://group.bmj.com/group/rights-licensing/ permissions 